\title{
“The Writer Is Essentially Indiscrete." On the Literary Gossip of a Dutch Literary Celebrity
}

\author{
SANDER BAX \\ Tilburg University \\ Tilburg School of Humanities \\ Department of Culture Studies \\ Tilburg University \\ Warandelaan 2 \\ 5037 AB Tilburg, The Netherlands \\ p.a.bax@uvt.nl
}

\begin{abstract}
In contemporary media culture, literary writers arouse the fascination of media fans by awakening in them the desire for the authentic by publishing autobiographical novels or other forms of life narrative. In doing so, they run the risk of becoming part of media's large gossip mechanism that plays such a central role nowadays. The public conversation about the books of writers such as the Dutch author Connie Palmen - whose Logboek van een onbarmhartig jaar will be the main case study of this article - becomes focused on the elements of truth and authenticity and ignores the literary or fictional construction of the work. This article discusses the question whether this leaves any room for contemporary star authors to distinguish themselves from media gossipers.
\end{abstract}

Keywords: literature; gossip; literary celebrity; Connie Palmen; fiction; media culture

\section{Introduction}

In contemporary media culture, literary writers need to take up the position of public celebrity in order to gain public attention. ${ }^{1}$ The rise of the literary celebrity

\footnotetext{
${ }^{1}$ See for the most relevant literature on this topic: Collins 2010; Moran 2005; Franssen 2010; Bax 2015 and 2016; Heynders 2016a en 2016b, Franssen and Honings 2016 and 2017.
} 


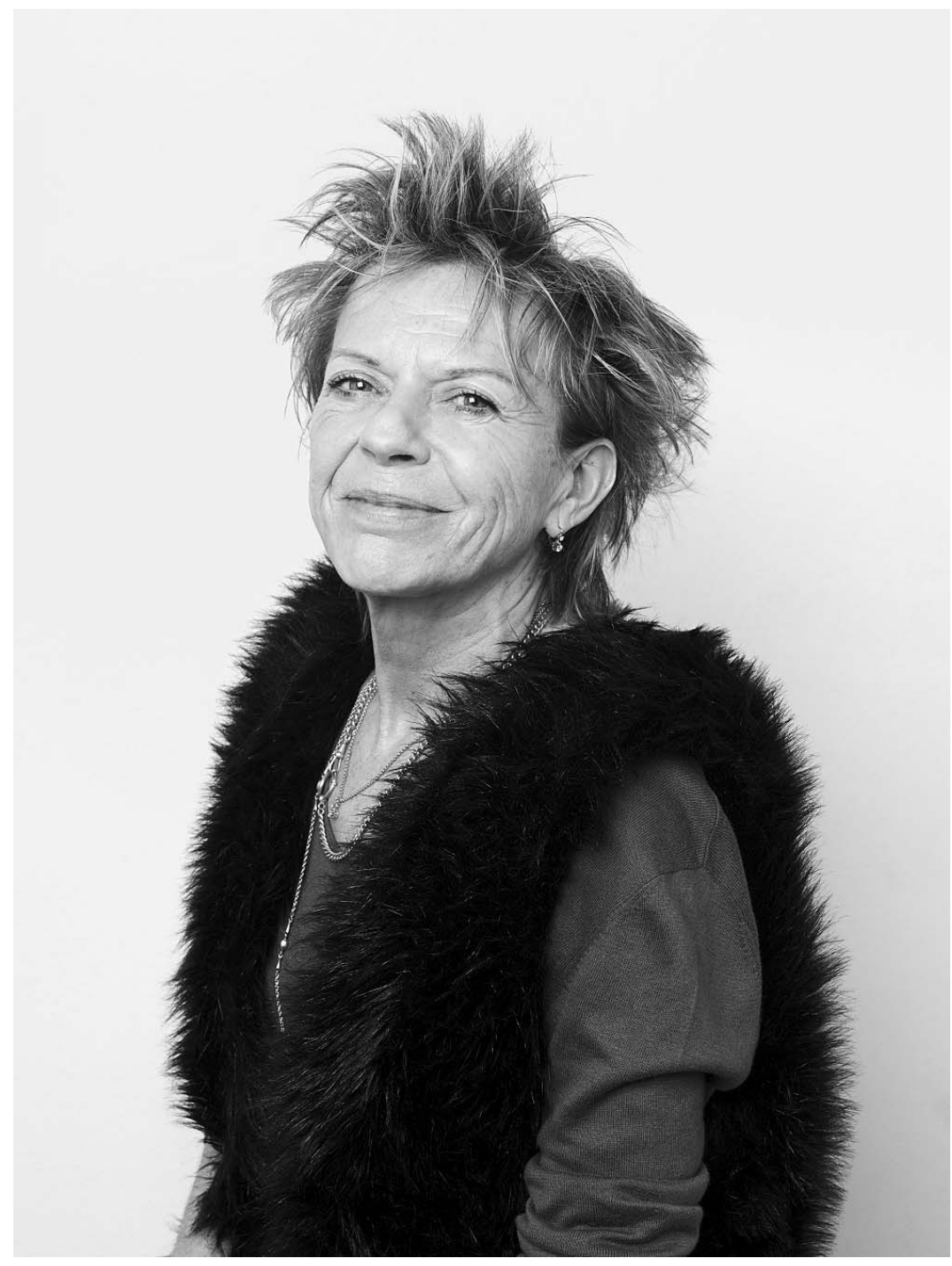

Connie Palmen. Photo: Annaleen Louwes 
has been a central issue in important studies by Joe Moran (Star Authors, 2005) and Gaston Franssen and Rick Honings (Idolizing Authorship, 2017). One of the complexities of celebrity authorship that I will be discussing in this article, is the increasing demand for authors to be authentic and intimate in contemporary media culture (Sennett 1977; Linke 2011). Television viewers, newspaper readers, and the book-buying public, all seem to have a desire for really knowing about the authentic life of the celebrity (Langer 2006: 181-195).

This makes for a strong connection between contemporary celebrity culture on the one hand and the dominance of 'the autobiographical' on the other. For literature, this results in a fascinating paradox. Literary writers, of course, are the specialists in autobiographical writing or life writing (Smith and Watson 2001). That might be one of the main reasons, I would suggest, why literary writers gain so much attention in our contemporary media culture. But "with every win comes a loss": literary writers who arouse the fascination of media fans by awakening in them the desire for the authentic also run the risk of becoming part of media's large gossip mechanism (Bax 2016, 2017). The public conversation about their books becomes focused on the elements of truth and not on the literary or fictional construction of the book. Does this leave any room for literary writers to distinguish themselves from media gossipers?

\section{The 'personality system' in celebrity culture}

Where does this desire for the authentic and the intimate come from? Media theorist John Langer (2006: 182) claims that a "personality system" is at the root of late $20^{\text {th }}$ century and early $21^{\text {st }}$ century television and media culture. With the rise of television, Langer claims, film stars started to transform from godly creatures the people admired into 'normal' beings the viewer could identify with. Television viewers regard television stars as 'ordinary' people with 'real lives' that they could really get to know (Dyer 2006: 153-176; Marshall 2014; Turner 2014; Heynders 2016b). That is why television 'personalizes.'

"Good television" also personalizes whenever it can, rarely using a concept or idea without attaching it to or transforming it through the "category of the individual." As a result, "good television" is television that embodies and articulates a world of "personalities" who thoroughly penetrate and organize its viewing agendas, or enter television by being on those agendas. (Langer 2006: 182)

To explain this communication situation, Langer (2006: 185) points to the fact that television is watched "in the comfort of our own home" - in contrast of course to the classic situation of film watching in the cinema theater. The television itself 
has become an integral part of our living room and television viewing has become an integral part of our daily routines. In that sense, television never stops and is always there. Langer claims that this communicative situation makes for the fact that television watching - and as a result also participating in the television celebrity system - is all about creating relations of "intimacy" and "familiarity" between television stars and television viewers.

The act of television watching is found in the intimate and familiar terrain of everyday life where we receive television's own "intimacies" and "familiarities" brought to us through its personalities. This correspondence between the intimacy structure of television watching and the way in which intimacy is structured through the personality system forms one of the major conditions through which television negotiates effectively to win the consent of audiences and to render invisible its ideological work. (Langer 2006: 186)

It is easy to see that this 'personality system' was dominant in the classic, pre-programmed television culture that was dominant in 1981 when Langer first published this important article. Since then, a lot has changed in the way we watch television and the way we use media in general. Strangely enough though, one thing doesn't seem to have changed: the dominance of the 'authentic,' the 'intimate' and the 'private' when it comes to public talk about stars, celebrities and other kinds of media celebrities. I would suggest that it would be worthwhile to consider Langer's 'personality system' not only as representative for television culture, but as a system that underpins contemporary media culture in general.

In the book Real Lives, Celebrity Stories, media specialist Craig Batty (2014: 36) claims that "whatever type of media text we are engaging with, we are experiencing someone's story: ours (personal essay or video diary), theirs (Facebook page or newspaper article), even something's (a car or a washing machine advertisement)." Batty pinpoints the 'character' as the most important feature. Characters guide viewers through the mediatized narrative and therefore characters are fundamental to the way media work: "We take pleasure in the narrative because we understand what it is trying to achieve; and because we need someone or something to guide us through the narrative - a central identification figure - we psychologically connect to the character as away of rendering meaning possible" (Batty 2014: 39).

How deeply this way of thinking has influenced literary culture becomes clear when we consider a quote from David Shields' influential essay Reality Hunger: "The implied secret is that one of the smartest ways to write fiction today is to say that you're not, and then to do whatever you very well please. Fiction writers, take note. Some of the best fiction is now being written as nonfiction" (Shields 2010: 20). Shields' claim in 2010 is quite explicit: to make literature relevant for 
the $21^{\text {st }}$ century it has to pretend not to be fictional. This immediately provides us with a problem, for many scholars have equated fiction with literature. Can there be literature without fiction? What do concepts like reality, authenticity, and actuality mean when we discuss literature? And how are they operationalized in the mass media?

\section{Reality and fiction in literature and media}

The literary novel has problematized the relation between fiction and reality for decades. In a novel, an author creates a new (alternative) world, that more or less resembles a world outside the book (or that creates an image of a world outside the book). The effect of the language situation we come across in most novels is that readers get immersed in a story world on the one hand, but on the other hand remain conscious of the fact that this world is made and constructed, not real and thus fictional. According to literary scholar Werner Wolf (2016: 6) this movement of "immersion" and "representationality" determines the "aesthetic illusion" that literary fiction creates. He speaks of "a feeling, with variable intensity, of being imaginatively and emotionally immersed in a represented world and of experiencing this world in a way similar (but not identical) to real life" (Wolf 2016: 6). The reader gets immersed so intensively in the text that he experiences the text as if it is real, but "this impression of immersion is counterbalanced by a latent rational distance resulting from a culturally-acquired awareness of the difference between representation and reality" (Wolf 2016: 6). This double movement of fiction determines the impact of the $19^{\text {th }}$ and $20^{\text {th }}$ century novel, but Elena Esposito has shown that the relation between reality and fiction (or virtuality) has a far broader impact in 21st-century culture.

The events related in novels are not true, but neither are they false. They constitute a "second reality" that accompanies our real world of reference and enable us to assume the viewpoint of other characters, to live the lives of others to some degree and gain experience that we then apply also in running our own. The function of fiction in modern society lies essentially in this interweaving of different realities, where worlds that do not exist also have real consequences through their capacity to affect our perception and interpretation of "actual reality" [...]. (Esposito 2010: 3)

But how does the aesthetic illusion of literary fiction relate to the non-aesthetic illusion we encounter in mass media culture? The discourses of radio, television and (social) media may come across as real and authentic, but they too are the result of (ideological) constructions. The narrative structures of television 
shows are constructed to have viewers identify themselves with the people on the screen: immersion is a fundamental, intended effect. To achieve that, television makers emphasize the 'reality behind the text': autobiography, human interest and disclosure. The public media create a reality too and sometimes it is the stain on our television screen or the crack in our laptop that reminds us of the fact that what we see is not real but represented.

Here we stumble across what might turn out to be an important difference between literature and media. Literature - at least in its $19^{\text {th }}$ and $20^{\text {th }}$ century more or less modernist manner - wants to stage its fictionality, whereas public media want to hide their fictionality as much as possible. The maker of an opinion-show is not interested at all in the shuttle movement between immersion and representationality that dominates literary fiction. On the contrary, the longer viewers are immersed, the longer they will believe the language game the television show is performing, the longer they will keep watching. In the language game of media culture the problem of fiction is not performed (as it is in literature) but it is denied as much as possible.

This is exactly what happens when literary novels are being discussed on television. Interviewers and documentary-makers focus on the element of immersion, on the reality behind the text, on the credibility of what is being portrayed in the novel. The result is that the media culture constructs the literary author (or the literary celebrity) not as a person who is able to construct subtle alternative worlds (let's say: as an author), but as a person who has experienced the events that the novel narrates (that is: as the main character of the novel). Of course, this is mostly the case when the literary text has a life writing-character. But sometimes the mechanism is used in cases when the conversation revolves around an explicit fictional novel too (Bax 2017). In media conversations, the constructed, non-real, fictional character of the literary work has to be hidden as much as possible: viewers have to be given the impression of watching a real, authentic and credible person. I would consider this a very crucial observation in analyzing what happens when literary writers perform on the platforms of mass media.

The observation also sheds a critical light on the relevance of Shields' reality hunger. David Shields prescribes a return to reality as a recipe for the contemporary novel to become relevant again. I would claim in contrast to this that literature's desire for reality and authenticity is the direct result of its desire to maintain a central role in today's mass media culture. By adapting to the discursive laws of media culture, literature indeed keeps playing a central role in a variety of media contexts, but that comes with a price: to gain attention from a larger section of the public writers have to present their novels as if they are something else than novels. One of the many forms in which literature 
emerges in media culture is gossip - and that will be my point of departure for the in-depth case study I will present in this article.

\section{Gossip in celebrity culture}

If the exchange of intimate details about a person about whom readers and viewers really want to know everything about, is one of the corner stones of contemporary media culture, than it cannot come as a surprise that gossip plays such a central role nowadays. In quite a useful article, Eric Foster, from the Institute for Survey Research at Temple University in Philadelphia, claims that gossip about public figures is part of an enormous cultural and economic enterprise (Foster 2004: 85). Gossip mostly involves the public conversation about negative things that happen in the private lives of celebrities that they would rather have kept to themselves. On the other hand, in media culture, being the object of gossip discourse also creates a lot of media attention for the celebrity and thus is part of the celebrity economy (Van Krieken 2012). Many celebrities are aware of the fact that the press has to be offered small private scandals to write about, as a strategy for keep getting media attention.

Foster (2004: 83) comes to a simple but elegant definition of gossip that will inform my elaboration on the relation between gossip and literature: "In a context of congeniality, gossip is the exchange of personal information (positive or negative) in an evaluative way (positive or negative) about absent third parties." This definition contains four important elements. Gossip often consists of the exchange of social and personal topics, but this exchange has to be "an exchange of information about absent third parties": A and B are talking about C (Foster 2004: 81). Foster reflects on the question of whether gossip has to include intentionally told bad things about the absent person. In the popular understanding of the concept, he claims, the element of negative evaluation is crucial to speak about gossip. But he nuances this idea by claiming that every exchange of human news will be colored by evaluation. Because it has been shown that malicious gossip only takes up a small part of the conversational time, Foster (2004: 82) decides to include both negative and positive evaluation in his definition (Foster 2004: 82). Finally, he considers the contextual situation in which gossip takes place, which often is a context of "intimacy," "gusto" and often of "surprise and revelation."

Why is gossip so dominant in our media culture and in our lives in general? Foster comes up with several important social functions: gossip provides people with (social) information, it makes for recreation and entertainment, it strengthens friendship connection by creating a bond of intimacy between A and B, and 
it creates group solidarity (Foster 2004: 83-84). It has been remarked that gossip goes back to a crucial anthropological function: communities constitute themselves by saying bad things about individuals the community excludes. Literary scholar Wilbert Smulders has convincingly connected the function of gossip in $20^{\text {th }}$ century media culture with René Girard's anthropological theories about the so-called 'scapegoat mechanism' (Girard 1986; Smulders 1997). For communities to be coherent, they need to point out one of the community members as a scapegoat. When they are able to exclude the scapegoat, the community will remain stable. In classical times, rituals and myths had the function of creating stories that justify the fact that the scapegoat has been found guilty. It is in the storytelling that he is construed as the guilty one. Smulders (1997) would claim that contemporary gossip narratives more or less serve the same goal as the classic rituals and myths.

In this article, I will try to shed some light on the question of what the connection between gossip and literature teaches us about the paradoxical position of the literary writer as a media celebrity. Of course, literary writers as celebrities can become the subject of media gossiping just like any other kind of celebrity (did the writer get divorced? Rumours are heard that famous writer $X$ has been ill for a few months? Writer $Z$ will finally publish his revelatory autobiography!). But the literary writer can also end up at the other end of the spectrum: literary writers in media culture can also become the public figures who take up the pen or the camera to produce media stories and by doing so, gossip about other celebrities and become the backbiter themselves. But I don't want to dwell too long on these kinds of examples, for I think there is a more important and more fascinating connection between literature and gossip. I would claim that literature and gossip make use of a quite similar language situation. In a novel, a narrator is providing the reader, in an evaluative manner, with all sorts of personal and social information about an absent third party (the character), in a context of intimacy and often also surprise and revelation.

The language game we enter when reading a novel looks very much like the language game that is involved in gossip. Does that mean that the novelist is the backbiter par excellence? Especially, when the story told in the novel resembles events that we know have been happened outside the book and when the absent third party is quite similar to someone who exists outside the book. If it is not the novelist in general who is the backbiter par excellence, then maybe the autobiographical writer is? In an autobiographical novel, a collection of letters, a diary, or any kind of text in which authors write about their own life, two things happen. Narrators provide their narratees with personal and social information about people that are present in the personal life of the writer and narrators share personal and social information about their own lives. 


\section{The paparazzo writer}

As a case study for investigating the connections between celebrity gossip and literature, I will focus on a book published by Dutch star author Connie Palmen in 2011. In 2009, five months before he would die of liver cancer, Palmen married the man she had been living with for years, former Dutch minister of Foreign Affairs and Deputy Prime Minister Hans van Mierlo. Logboek van een onbarmhartig jaar [Logbook of a Cruel Year] is a diary-like book, in which Palmen wrote extensively about the illness of Van Mierlo and about her own period of grieving after he had died, including the alcohol problems and the family conflicts that came with that (Palmen 2011).

In the novel, Palmen thematizes the similarity between gossip and (autobiographical) writing. One day she is scrolling through the internet in search for pictures taken at the funeral of Van Mierlo. She finds out that the 'famous' Dutch paparazzo photographer Peter Smulders has documented the entire day. Contrary to what we might expect, she doesn't react negatively: "The ambiguous entanglement of good and evil touches me. Preserved by gossip photography. The paparazzo extends the remembrance of my life story. It is the Judas-theme, it is the essence of literature, it is the goodness of betrayal, betrayal as the necessary condition for knowing, for revelation" (Palmen 2011: 85). ${ }^{2}$

When discussing the book on the popular Dutch late night talk show Pauw $\mathcal{E}$ Witteman, the topic pops up again. Host Jeroen Pauw points at the fact that paparazzi photographers are mostly accused of doing inappropriate things. Palmen explains why she was happy with their existence. The photographer provided her with a "filmed narrative" of the day they buried Van Mierlo. She was happy to notice, for she had forgotten a lot of things already. "So, I was intensely grateful to that man. I think: long live the paparazzi!" (Pauw E Witteman, 10.11.2011). ${ }^{3}$ Then she emailed him to ask for the pictures he had taken of her. "So he gave me the whole reportage of that day, it became my possession. He hadn't just been a thief of the images of my life, he gave it back" (Pauw $\mathcal{E}$ Witteman, 10.11.2011). ${ }^{4}$

It is the paparazzo who provides the celebrity with "the images of her life" and in doing so contributes to the logbook she is writing - a book that in itself

\footnotetext{
2 “De dubbelzinnige verstrengeling van het goede en het kwade raakt me. Bewaard door de roddelfotografie. De paparazzo verlengt de herinnering aan mijn geschiedenis. Het is het thema van judas, het is de essentie van literatuur, het is de goedheid van het verraad, het verraad als noodzakelijk voorwaarde voor het kennen, voor de openbaring." (Unless otherwise noted, all translations from Dutch are my own - SB).

3 "Dus ik was die man intens dankbaar. Ik denk: leve de paparazzi."

4 "Dus ik mocht die hele reportage, van die dag, werd ook mijn bezit. Het was niet alleen een dief van beelden van mijn leven, hijgaf hetterug." < http:/ / pauwenwitteman.vara.nl/Artikel.4215.0.html?\&tx_ ttnews\%5Btt_news\%5D=23953\&cHash=2ff453f6bb7bde813bc3ccf4cc48ff63/>, <https:/ /www.youtube.com/watch?v=tAMfO-8wr_I>, retrieved 3 Dec. 2017.
} 
is sometimes criticized for using a gossipy discourse about Van Mierlo and his relatives. At the end of the book, Palmen points to a question that her sister-in-law Marie put to her one day - a question almost every interviewer asks her too - why she is so 'shamelessly' honest about her life with Hans van Mierlo. She shouldn't write all these things down. Palmen responds: "Laymen and readers have a completely different idea about what is private and what is not than authors do" (Palmen 2011: 170-171). ${ }^{5}$ It is the task of the writer, she claims, to lay bare her own life in a merciless way and that implies that she has to lay bare the life of others that surround her as well. That is why Palmen compares the writer to cultural figures such as Lucifer and Judas: "Lucifer and Judas, that's me, that is someone who hooks in someone else so intensely that only betrayal, murder, death can end it. Just like I'm captured by that desire for love, I am captured by an always latent desire for the rupture, for destruction" (Palmen 2011: 86). ${ }^{6}$

In the interviews that accompanied the release of the book, Palmen made clear that one major theme in the book was the Judas-theme. In the book, it says: "At the moment the writer picks up the pen, he is a Judas." Writing, therefore, "is always some sort of betrayal."

People tend to forget that 'revelation' is a second meaning of the word betrayal. You just said: 'you lighten up!' That betrays, reveals something. The essence of literature is that it reveals something that cannot be known in any other way. That's why this book, and literature in general, by definition is shameless, treacherous. (Riemersma 2011) ${ }^{7}$

This issue pops up in every interview Palmen gives. How far does she want to go in portraying the details of the intimate and private life of the people that surround her, and of Hans van Mierlo and his family in particular? The interviewers tend to use a double standard in their questions: on the one hand, they are looking for even more details ("Were there things you left out?"), on the other, they adopt a more normative position ("How do you feel about making all these details public?"). In the Dutch television show Pauw \& Witteman, Palmen claims not to be afraid of being too "open-hearted" or of being too "impudent."

\footnotetext{
5 “Leken en lezers koesteren een volstrekt ander idee over wat privé is en wat niet dan wij, de schrijvers."

${ }^{6}$ "Lucifer en Judas, dat ben ik, dat is iemand die zo in iemand anders haakt dat alleen verraad, moord, de dood er een einde aan kan maken. Zoals ik behept ben met dat liefdesverlangen, zo ben ik behept met het altijd sluimerend verlangen naar de breuk, naar de vernietiging."

7 "Mensen vergeten dat een tweede betekenis van verraad 'openbaring' is. Jij zei net: 'Je gaat helemaal stralen.' Dat verraadt, openbaart iets. Ik vind de essentie van literatuur dat ze iets openbaart wat op geen enkele andere manier gekend of geweten kan zijn. Daarom is dit boek, literatuur in het algemeen, per definitie schaamteloos, verraderlijk" (Riemersma 2011).
} 
Look, I am not afraid of being 'open-hearted,' and I am not afraid of what others might call 'shameless' - or whatever terms they have at hand. As a writer I don't have that much trouble with impudence. If I had, I wouldn't have been a writer! I think I became a writer because I am ashamed a lot in daily life, not only for myself, but also for others. And when I write, that is gone. This doesn't mean that I am unable to censure my own work at this point. But I think a certain amount of indiscretion is an element of good literature. And impudence. Literature lays bare what others really say, that is what literature does. They read it eagerly and then they say: "vicarious shame!". And "voyeurism!". (Pauw \& Witteman, 10.11.2011) ${ }^{8}$

Logboek van een onbarmhartig jaar is explicitly called a logbook and not a novel, so this is a clear example of a life narrative (Smith and Watson 2001; Missinne 2013). The narrator of the text resembles the author Connie Palmen, the third party resembles Hans van Mierlo and the events resemble the time frame from January 2010 until September 2011, the period that covers the last months of Van Mierlo's life (January-March 2010) and the period of Palmen's grieving over his death (April 2010-September 2011). Along the way, narrator Connie Palmen provides her readers with a lot of intimate and personal information about the absent Hans van Mierlo.

He has been in bed for six weeks now, without being able to walk. Tomorrow morning, I will massage his legs, arms, belly, shoulders and neck, and I'll do his exercises with him. Then I'll crawl to the end of the bed, lay his legs on my neck and swing him back and forth. Or I'll put his feet on my chest and have him push me away. We laugh. He is proud. He still has a lot of strength in his legs. That comforts me. "How strong you are," I say, "and how beautiful!" To stop the oedema in his feet and lower legs, Aischa will put on his tight stockings in a minute. Because of the air circulation the stockings have large holes at the end that make the knuckles of his toes visible. When Aischa put them on for the first time, he smiled and looked at his bandaged feet. "My small Muslim Women," he said to her. If it is possible, I'll ask the physiotherapist to come tomorrow morning with the hoist and the hanging bag. He loves to be lifted

\footnotetext{
8 "Ja, kijk, voor openhartigheid ben ik niet bang, ook niet voor wat anderen zullen bestempelen als schaamteloos. Of, god, er zijn vast nog meer termen voor. Daar heb ik namelijk als schrijver buitengewoon weinig last van. Ik was anders ook geen schrijver geweest. Ik denk namelijk dat ik mede schrijver ben geworden omdat ik me in het dagelijks leven juist bovenmatig schaam, niet alleen voor me zelf, ook vaak voor anderen. En dat heb ik als ik schrijf niet. Neemt niet weg dat ik nog mijn eigen werk ook kan censureren op dat punt. Dus ik vind het zelfs een element van goede literatuur, een mate van indiscretie. En schaamteloosheid. En dat wat de literatuur doet, namelijk het blootleggen van iets wat anderen eigenlijk zeggen. Ze lezen het gretig uit en dan zeggen ze plaatsvervangende schaamte. En voyeurisme."
} 
up, seemingly light and weightless, floating between heaven and earth for a while, to be cradled like a child. (Palmen 2011: 222) ${ }^{9}$

\section{The promise of truth}

In December 2010, more or less nine months after Hans has died, Connie Palmen learns that Hans's daughter Marie is terminally ill too. When she reflects on the news, she is writing an essay for the magazine CPhoto. As a starting point for her essay, she takes the pictures Annie Leibovitz made of the recently-deceased Susan Sontag. A picture we know has aroused a lot of discussion about the boundaries between private and public, mostly because of the severe criticism of Sontag's son David Rieff. Palmen remarks that Rieff himself has written memoirs about the death of his mother: "But Leibovitz' desire to take the pictures and to make them public, comes from the same source as the son's desire to describe his mother's death bed and to publish it. Memoirs are the snapshots of literature" (Palmen 2011: 184). ${ }^{10}$

In discussing the Leibovitz-case, Palmen acknowledges that she feels that she is doing more or the less the same in her book on Hans van Mierlo. Not only did she herself take pictures at Van Mierlo's death bed, she also makes a lot of private details about his dying days public, as we have seen in the previous quotation. Palmen continues her essay - which she embedded in the logbook - with a passage that theorizes the concept of fame. The effect of fame is that a giant leap exists between public and private: when one becomes famous, one has two lives: a public one and a private one.

Fame learns how easily one changes into an object, a thing in the eyes of others, deprived of your humanity and therefore an object of expropriation. The language used to describe the work of paparazzi betrays

\footnotetext{
9 “Hij ligt al bijna zes weken in bed, zonder nog een stap gezet te hebben. Morgenochtend ga ik zijn benen, armen, buik, schouders en nek masseren en oefeningen met hem doen. Dan kruip ik naar het voeteneind, leg zijn benen op mijn schouders en schommel hem heen en weer, of ik zet zijn voeten tegen mijn borst en laat me door hem wegduwen. We lachen. Hij is trots. Hij heeft nog behoorlijk veel kracht in zijn benen. Dat stelt me gerust. 'Wat ben je toch sterk,' zeg ik, 'wat ben je toch mooi.' Om de zwelling in zijn onderbenen en voeten tegen te gaan, trekt Aischa hem zo dadelijk strakke steunkousen aan. Voor de luchtcirculatie hebben ze een langwerpige opening aan de uiteinden waarin de knokkels van zijn tenen nog net zichtbaar zijn. Toen Aischa ze hem voor het eerst aantrok keek hij lachend naar zijn ingepakte voeten. 'Mijn kleine Moslima's,' zei hij tegen haar. Als het even kan laat ik morgen op het einde van de ochtend de fysiotherapeuten met de takel en de hangzak langskomen. Dat vindt hij heerlijk, omhooggetild worden, schijnbaar licht en gewichtloos te zijn, even tussen hemel en aarde te zweven, gewiegd te worden als een kind."

10 "Maar het verlangen van Leibovitz om de foto's te maken en te openbaren, komt voort uit dezelfde bron als het verlangen van de zoon om het sterfbed van zijn moeder te beschrijven en te publiceren. Het genre van de memoires is het snapshot van de literatuur."
} 
a violence essential to photography. The paparazzo is the hunter, the celebrity his prey. The hunt is not aimed at the portrait as such, but at a picture that is shocking and that discloses secrets. To be caught, the prey has to think he is unseen. Only then, will he show his true self. (Palmen 2011: 185) ${ }^{11}$

Palmen creates an opposition between 'the true self' of the unseen celebrity and the mask the celebrity is wearing when conscious of being in public. The paparazzo - and by implication the autobiographical writer - is hunting the celebrity for moments of unconsciousness.

Scratching, yawning, shouting, crying, adulterous, naked. The moment a public person goes onto the street and enters the public domain, he is outlawed. Any moment there is the possibility of him being surprised, disclosed, paralyzed, imprisoned, caught, shot. In the best case, the hunter shoots with the blanks of word or light. In a time where photographers themselves are increasingly disclosed as false manipulators of the image, as the directors of a play being sold as reality, paparazzi with their snapshots keep relying on another essential characteristic of photography: the promise of truth. (Palmen 2011: 185) ${ }^{12}$

Here, Palmen points to the mechanism with which I started this article: the notion that photographers (and maybe in times of fake news all media makers) are sometimes considered to be "manipulators of the image," but that paparazzi photographers and literary writers keep relying on "the promise of the truth." It is the authenticity that their photographs contain as a result of the very 'real' images they portray, that makes the viewer and the reader forget that these photos too are constructions and, by implication, false. It is the betrayal of the object of the photograph, the betrayal of the beloved one, that fills the image - or the text, for that matter - with the idea of truthfulness that defines its success. This is why the writer and the paparazzo are connected to the character of Judas, which is a main theme in Logboek van een onbarmhartig jaar. Palmen considers the Judas-theme essential to literature.

\footnotetext{
11 “Roem leert je hoe gemakkelijk je in de ogen van anderen verandert in een voorwerp, een ding, ontdaan van menselijkheid en daarom een object voor onteigening. De taal waarmee het werk van paparazzi wordt omschreven, verraadt een aan de fotografie wezenseigen gewelddadigheid. De paparazzo is een jager, de beroemdheid zijn prooi. De jacht is er niet eens op de beeltenis pur sang, maar op een foto die choqueert en geheimen onthult. Om gesnapt te worden moet de prooi zich ongezien wanen, alleen dan geeft hij zijn ware wezen prijs."

12 “Krabbend, gapend, scheldend, huilend, overspelig, naakt. Zodra een publiek persoon de straat op gaat en het openbare domein betreedt, is hij vogelvrij. Steeds ligt daar de mogelijkheid op de loer dat hij wordt betrapt, onthuld, lamgelegd, gevangen, gesnapt, geschoten. In het gunstigste geval schiet de jager met de losse flodders van het woord of met die van het licht. Terwijl de fotografen zelf steeds meer werden ontmanteld als bedrieglijke manipulators van het beeld, als regisseurs van een toneelstuk dat als werkelijkheid wordt verkocht, blijven de paparazzi met hun snapshots teren op wat ook van oudsher een wezenskenmerk van de fotografie is: de belofte van de waarheid."
} 
The writer is essentially indiscrete. He is the traitor, the revealer, the discoverer. He is the enemy of the silent congregation, the dark family secret, the mysterious conspiracy, the group, the club, the institute. Shameful, cautious, discrete, introvert and charming when he is among people, whenever the writer takes up the pen he becomes Judas. (Palmen 2011: 20) ${ }^{13}$

When everyone keeps up appearances, manipulating their images, this "essentially indiscrete" writer functions as what Palmen calls "traitor, revealer and discoverer" at the same time: literature promises the truth behind the mask, the true story. One of the central elements of Logboek van een onbarmhartig jaar is that Palmen argues she is keeping the private Hans van Mierlo alive, the 'real' person that has existed behind the public figure Van Mierlo. In order to do that, she has to enter in her novel the "sensibility of the memory, the intimacy of it" (Palmen 2011: 38). ${ }^{14}$

The public man doesn't roast quails for you [doesn't make tea for you, SB], doesn't bring you breakfast in the morning, doesn't caress you, doesn't embrace you, doesn't cherish you, doesn't say my love, my little kitten, my sweetheart. [...] You don't love someone for what he is good at, for what gave him his name in the world. You love his shortcomings, his weaknesses, his innocence. (Palmen 2011: 38) ${ }^{15}$

This tension between private and public is also subject of debate on the talk show table on 10-11-2011. The discrepancy between the public Van Mierlo and the private Van Mierlo started immediately after she came home from the funeral. That evening Pauw en Witteman had dedicated their show completely to the former politician, but Palmen wasn't able to look at it. Host Jeroen Pauw asks whether she was surprised or touched by the fact that other people were grieving about a public figure, someone so different from the private person she had known: "O no, I understand that very well, I got used to it. That doesn't mean that I want to be part of it, I do not want to be part of that public. Not even as a viewer of my own husband as a public figure" (Palmen in Pauw \& Witteman, 10.11.2011). ${ }^{16}$

Here we encounter the paradox that this case study lays bare. On the one hand, Palmen keeps emphasizing the differences between the public Van Mierlo

\footnotetext{
13 "De schrijver is per definitie indiscreet. Hij is de verrader, de onthuller, de ontdekker. Hij is de vijand van het stilzwijgende verbond, van het duistere familiegeheim, van de mysterieuze samenzwering, van de groep, de club, het genootschap. Schaamtevol, omzichtig, discreet, introvert en innemend in de omgang, zodra de schrijver de pen oppakt, is hij een judas."

14 "zinnelijkheid van de herinnering, de intimiteit ervan"

15 “De publieke man braadt geen kwarteltjes voor je, brengt je's ochtends geen ontbijt op bed, streelt je niet, omarmt je niet, bemint je niet, zegt niet mijn duifje, mijn hondje, mijn hartendiefje. [...] Je houdt niet van iemand om waar hij goed in is, waarmee hij naam heeft gemaakt in de wereld. Je houdt van zijn onvolkomenheden, van zijn zwakheden, van zijn onschuld."

${ }^{16}$ "O nee, dat begrijp ik heel goed, daar ben ik aan gewend geraakt. Dat betekent niet dat ik er deel van wilde uitmaken, ik wilde geen deel uitmaken van dat publiek. Zelfs niet als kijker naar mijn man als publiek figuur" (Pauw \& Witteman, 10.11.2011).
} 
(on television, on photographs) on the one hand and the private Van Mierlo on the other (the man who makes you breakfast). Her own logbook gains authenticity and credibility through the fact that it contains a portrait of that private man. The fact that Palmen shares personal information about this private man we all know, with us, makes for the gossipy element of the book. So she has to betray the private man on behalf of her authorship. And by doing so, she turns the private into public, minimizing the private and maximizing the public image.

\section{The language of the media}

The cover of the novel emphasizes the autobiographical and 'true' nature of the book: "The logbook is a touching report of the craving for a vanished body, of self-loss, of anger, and of the loving memories of a beautiful man" (Palmen 2011, cover). ${ }^{17}$ In these kinds of commercial texts we often find telling genre indications such as 'report' and 'memories' that suggest a direct, mimetic relationship to reality. This promises the reader that the book provides direct immersion in the reality of the story, the "promise of the truth" Palmen was referring to.

But despite that this logbook also contains several moments that obstruct the immersion and point the reader to the fact that the book is constructed and written. In the book, Palmen constantly makes this problem explicit. She speaks about her working on the book as "not really writing," and that's why the book makes her shameful.

You cannot really call it writing. You are writing when you have found a form, a structure that connects the sentences, a set of ideas that keeps them together, that chases them and directs them. These unrestrained notes do not deserve the name.

They embarrass me.

I am embarrassed by the fact that I am writing, by the way I am writing. (Palmen 2011: 15) ${ }^{18}$

Palmen also criticizes the notion of 'pure fiction' and 'imagination.' In her writing now, she can't stand all these literary constructions, these layers of meaning. The difference between literature, construction, technique on the one hand and

\footnotetext{
17 “Het logboek is het aangrijpende verslag van de hunkering naar een verdwenen lichaam, van zelfverlies, woede, en van de liefdevolle herinneringen aan een prachtige man."

18 "Schrijven kun je het niet noemen. Schrijven doe je als je een vorm hebt gevonden, een structuur die de zinnen onderling verbindt, een span ideeën dat ze bijeenhoudt, aanjaagt en stuurt. Deze teugelloze aantekeningen verdienen de naam niet.

Ik schaam me ervoor

Ik schaam me dát ik schrijf, en hóe ik schrijf."
} 
the truth in which she lives on the other is too big: "And it is even unthinkable to do what a novel would demand me to do: turning someone's fate into a plot" (Palmen 2011: 62). ${ }^{19}$

The reader of Logboek van een onbarmhartig jaar constantly alternates between immersion in the grieve and the sadness of the authentic and intimate human being, Connie Palmen, who is the main character of the book on the one hand, and the reflections of the struggling writer Connie Palmen, who is the narrator of the novel. This tension between immersion and representationality is essential to every fictional novel, but the tension between an I-character and an I-narrator is central to every form of life writing (Smith and Watson 2001; Missinne 2013). It makes this book quite paradoxical and complex. By emphasizing the reality of the narrated events the novel connects to the story that the public media tell about Hans van Mierlo and at some points provides that story with new gossipy elements. But at the same time Palmen uses elements from the tradition of the modern novel and denies the reader the comfort of full and continuous immersion by pointing at fictionality and representationality.

This paradoxical status completely disappears in Palmen's aforementioned performance on the Pauw \& Witteman show on 10-11-2011. The two hosts aim their questions constantly at the experiences of the character Palmen, what she felt at the time and on the intimate details she is willing to provide about Hans van Mierlo. One of the first questions Palmen is asked, is typical for this way of interviewing: "And how does that make you feel?" ${ }^{20}$ And when Palmen is asked to read a short fragment of the book, she mumbles: "Let's see how I deal with that." ${ }^{21}$ In both cases, Palmen is constructed as a novelistic character and not as the narrator of the book: she is the one who lived the events of the book and not the one who constructed the book.

This seems to be a recurring mechanism in contemporary media culture: in television shows we see that writers are interviewed as the characters of their books and not as the narrator or makers of the book. I will illustrate that by focusing on a specific moment in the interview when Jeroen Pauw asks Palmen about the pictures she took of him at this death bed. What did she want to document with that?

Yes, it is very difficult to explain when one hasn't experienced it oneself. Eh. Eh. What did I want to document? Sometimes I have to look at it - certainly in the beginning - to believe it was really true. Because one element of this extreme grieving that mourning is, is bewilderment, and I am sure

\footnotetext{
19 “En zelf doen wat de roman van me zou vragen, het machtige werk om van het lot een plot te maken, is ondenkbaar."

20 "Wat voor gevoel heb je daar dan bij?"

21 "eens kijken hoe dat bij mezelf valt."
} 
that the public recognizes that, all the people that knew him from the public sphere. It cannot be true that he is dead. Such a man, who did not have anything to do with death in his life. So this bewilderment takes a long time and is a very awkward sensation, for someone that has loved him so much as I did. The bewilderment constantly takes you into hell, you think, it is, but it can't be, that I will never see him again. It last a long time and it lasts, to be fair three days would be too long, but it lasts for months. I think that the concept of 'never again' is too big for the human imagination. (Palmen in Pauw \& Witteman, 10.11.2011) ${ }^{22}$

In her answer, Palmen combines the notion of reality ("to believe it was really true") with an elaboration on how it feels to grieve; she presents these emotions as "too big for the human imagination." In doing so, she enlarges the mimetic part of her book and reduces the imagination-part. This mechanism fits very well with the language game we know is central to mass media: in this novel, and in this conversation, we are promised the encounter with the real Hans van Mierlo (more real than we ever knew!) and we are confronted with the real emotions of writer Connie Palmen. Palmen's novel - and the way it is positioned in this television interview - plays on the need of television makers to openly gossip about public figures.

\section{Conclusion}

In their autobiographical work, literary writers gossip about others and about themselves. That makes these kind of books so attractive for media culture: if you invite Connie Palmen, you get to exchange personal details about both Van Mierlo and Palmen. Life narratives are very popular today for they appeal to the public's desire for authenticity, intimacy and reality. And interviewers get the chance to speak with the authors as if they were authentic, sincere, 'real' people - a personality worth being a part of the media's personality system. Contemporary literary star authors can use the media's gossip mechanism to increase the attention given to their work.

\footnotetext{
22 "Ja, dat is heel moeilijk uit te leggen als je het misschien niet eerder hebt meegemaakt. Eh. Eh. Wat wilde ik daarmee vastleggen. Ik moet er af en toe naar kijken - zeker in het begin - om te geloven dat het echt waar is. Want een element van dat extreme lijden dat rouw toch is, is de verbijstering, en ik weet ook zeker dat een publiek, dus de mensen die behoren tot, die hem alleen maar kennen uit het publieke domein dat ook hebben. Het kan toch niet dat hij dood is. Zo'n man die eigenlijk geen enkele verhouding had met de dood bij zijn leven. Dus die verbijstering die is voor iemand die zo veel van hem gehouden heeft als ik, die duurt heel lang en dat is een buitengewoon akelige sensatie. Die rukt jou ook voortdurend in een hel, je denkt, het is toch, het kan toch niet, dat ik hem nooit meer zie. Dat duurt heel lang, en dat duurt, eigenlijk zou drie dagen al te lang zijn, maar dit duurt maandenlang. Ik denk dat nooit meer is zo veel te groot voor de menselijke verbeelding."
} 
Authors of literary texts are simultaneously the backbiter and the object of gossip at the same time: they construct the gossip narrative on the one hand and are the character in the gossip story on the other. If we consider contemporary gossip narratives to have the same function as the classical mythical narratives in Girard's sense, they would portray what he calls the "romantic lie": the lie that the scapegoat is indeed guilty. But we have to consider that in his theory, modern literature has a different and unique role to fulfil. According to Girard, literature brings the Romanesque truth to light: it uncovers the mechanism of scapegoating. Literature, then, can either be the continuation of the gossip story or it can be the place where the mechanisms of gossiping and scapegoating are foregrounded (and in doing so criticized).

In media culture, one could say, literary gossip narratives might be the place where the mechanisms of contemporary gossip culture are laid bare. It can do so by thematizing its own gossiping and showing its own gossiping as a fictional and constructed way of narrating. By doing so, it has the potential of dismantling gossip's truth claims. This means that literature still has a fundamental role to play in contemporary media culture. As a place where the crucial mechanisms of media culture are used, portrayed, discussed and transformed. It might be possible to read Logboek van een onbarmhartig jaar as such a critical and relevant novel.

But I think that would be a far too comfortable analysis of literature's position in media culture. In media culture, as we have seen, we very much like to ignore the fact that every literary novel is constructed and therefore not real but fictional. We want to believe the story is authentic and real: in reading a book such as Logboek van een onbarmhartig jaar, we downplay the signs of fictionality, or even ignore them completely, and entirely focus on the signs of reference. We have seen that this is one of the central principles in contemporary media culture: although we know that the politician in the talk show has prepared his interview carefully, helped by his spin-doctors, despite of that we still want to believe that there is a real and authentic person speaking to us.

By focusing on authenticity and reality, media culture tends to erase the fundamental difference between literature and gossip. The paradoxical situation we end up with, is that the potential critical function of literature as a place in which gossip's mechanisms are laid bare is erased at the very moment the author him- or herself enters media culture to discuss the book itself. We have seen how media culture downplays the signs of fictionality and enlarges the signs of referentiality. A book such as Logboek van een onbarmhartig jaar can be read as a constructed and partly fictional book, but in the media conversation about the novel is appears as 'something other' than fiction: as a non-fictional text that refers to reality in an unproblematic way. This has 
a result that in media culture the essential difference between literature and gossip disappears and the critical potential of the novel is rendered invisible. The critical potential of the novel disappears at the same moment the author enters media culture to talk about the book. Maybe that is the real indiscretion of the literary writer.

\section{Bibliography}

Batty, Craig. 2014. "“Me and You and Everyone We Know.' The Centrality of Character in Understanding Media Texts." Real Lives, Celebrity Stories. Narratives of Ordinary and Extraordinary People across Media. Eds. Thomas Bronwen and Julia Round. New York / London: Bloomsbury Publishing USA. 35-56.

Bax, Sander. 2013. “The Nobel Prize and the European Dream. Harry Mulisch's European Authorship from a National and an International Perspective." Journal of Dutch Literature 4(2): 4-26.

. 2015. De Mulisch Mythe. Harry Mulisch: schrijver, intellectueel, icoon. Amsterdam: Meulenhoff.

. 2016. “De publieke intellectueel als literair populist. Het publieke schrijverschap van Leon de Winter." Nederlandse letterkunde 21(2): 97-129.

. 2 Oct. 2017. "Over de mediastorm rondom Griet Op de Beecks publieke bekentenis. Leven in de openbaarheid." Diggit Magazine. 3 Dec. 2017. <https://www.diggitmagazine.com/articles/leven-de-openbaarheid>.

Bax, Sander and Odile Heynders. 2016. “Imaginary Scenarios. Literature and Democracy in Europe." Pivot: A Journal of Interdisciplinary Studies and Thought 5(1): 247-276.

Collins, Jim. 2010. Bring on the Books for Everybody. How Literary Culture Became Popular Culture. Durham / Londen: Duke University Press.

Dyer, Richard. 2006. "Stars as images." The Celebrity Culture Reader. Ed. P. David Marshall. New York/London: Routledge. 153-176.

Esposito, Elena. 2007. Die Fiktion der wahrscheinlichen Realität. Frankfurt : Sührkamp. 2010 "The Reality of the World and the Realism of Fiction." Manipulating Reality: How Images Redefine the World. 3 Dec. 2017. <http://www.strozzina.org/ manipulatingreality/e_index.php>.

Foster, Eric. 2004. "Research on Gossip. Taxonomy, Methods and Future Directions." Review of General Psychology 8(2): 78-99.

Franssen, Gaston. 2010. "Literary Celebrity and the Discourse on Authorship in Dutch Literature." Journal of Dutch Literature 1(1): 91-131.

Franssen, Gaston and Rick Honings, eds. 2016. Celebrity Authorship and Afterlives in English and American Literature. Basingstoke: Palgrave Macmillan.

2017. Idolizing Authorship. Literary Celebrity and the Construction of Identity, 1800 to the Present. Amsterdam: Amsterdam University Press.

Girard, René. 1986. De romantische leugen en de romaneske waarheid. Kampen: Kok.

Heynders, Odile. 2016a. Writers as Public Intellectuals. Literature, Celebrity, Democracy. Basingstoke: Palgrave Macmillan. 
2016b. "Public and Private Posture: Zadie Smith (1975)." Celebrity Authorship and Afterlives in English and American Literature. Eds. Gaston Franssen and Rick Honings. Basingstoke: Palgrave Macmillan. 179-201.

Krieken, Robert van. 2012. Celebrity Society. London: Routledge.

Langer, John. 2006. “Television's 'personality system.'” The Celebrity Culture Reader. Ed. P. David Marshall. New York/London: Routledge. 181-195.

Linke, Gabriele. 2011. "The Public, the Private, and the Intimate. Richard Sennett's and Lauren Berlant's Cultural Criticism in Dialogue." Biography 34(1): 11-24.

Marshall, P. David. 2014. Celebrity and Power. Fame and Contemporary Culture. Minneapolis: University of Minnesota Press.

Masschelein, Anneleen, Christophe Meurée, David Martens, and StéphanieVanasten. 2014. "The Literary Interview. Towards a Poetics of a Hybrid Genre." Poetics Today 35(1-2): 1-49.

Missinne, Lut. 2013. Oprecht gelogen. Autobiografische romans en autofictie in de Nederlandse literatuur na 1985. Nijmegen: Vantilt.

Moran, Joe. 2005[2000]. Star Authors. Literary Celebrity in America. Londen: Pluto Press.

Palmen, Connie. 2011. Logboek van een onbarmhartig jaar. Amsterdam: Prometheus.

Pauw \& Witteman. 10 Nov. 2011. 3 Dec. 2017. <http://pauwenwitteman.vara.nl/Artikel.4215.0.html?\&tx_ttnews\%5Btt_news \%5D=23953\&cHash=2ff453f6bb7bde813bc3cc f4cc48ff63/>, <https://www.youtube.com/watch?v=tAMfO-8wr_I>.

Riemersma, Greta. 12 Nov. 2011. "Interview Connie Palmen." de Volkskrant.

Smith, Sidonie and Julia Watson. 2001. Reading Autobiography. A Guide for Interpreting Life Narratives. Minneapolis: University of Minnesota Press.

Turner, Greame. 2014. Understanding Celebrity. Los Angeles: SAGE Publications.

Sennett, Richard. 1977. The Fall of Public Man. New York: Penguin.

Shields, David. 2010. Reality Hunger. New York: Knopf.

Smulders, Wilbert. 1997. “Een stal vol zondebokken. Geweld en begeerte in De tandeloze tijd." Vooys 16(1): 55-76.

Wolf, Werner. 2016. "Illusion (Aesthetic)." The Living Handbook of Narratology. Ed. Peter Hühn. Hamburg: Hamburg UP. 3 Dec. 2017. <http://wikis.sub.uni-hamburg.de/ lhn/index.php/Illusion_(Aesthetic)>. 